\title{
Association of the Encapsulation of Bacillus anthracis with a 60 Megadalton Plasmid
}

\author{
By IKUO UCHIDA, * TSUTOMU SEKIZAKI, \\ KAZUNORI HASHIMOTO AND NOBUYUKI TERAKADO \\ National Institute of Animal Health, Tsukuba Science City, Ibaraki 305, Japan
}

(Received 3 August 1984; revised 6 September 1984)

\begin{abstract}
Virulent typical strains (Shikan, Morioka, Shizuoka) and Pasteur vaccine strains (no. 1, no. 2-H, no. 2-17JB) of Bacillus anthracis harboured two plasmid species with molecular masses of $110 \mathrm{MDal}$ and $60 \mathrm{MDal}$. All of the $110 \mathrm{MDal}$ plasmids isolated from the various strains showed indistinguishable patterns of digestion with restriction endonucleases. All the $60 \mathrm{MDal}$ plasmids were also indistinguishable. Strain Davis, which is encapsulated but is asporogenous and avirulent, harboured only the $60 \mathrm{MDal}$ plasmid while three non-encapsulated vaccine strains (34F2, Smith, Mukteswer) harboured only the $110 \mathrm{MDal}$ plasmid. Four nonencapsulated variant strains obtained from the encapsulated strains Shikan, Pasteur no. 1, Pasteur no. 2-17JB and Davis had lost the $60 \mathrm{MDal}$ plasmid, suggesting that encapsulation of $B$. anthracis may be associated with the $60 \mathrm{MDal}$ plasmid.
\end{abstract}

\section{INTRODUCTION}

Bacillus anthracis is normally pathogenic, mainly to herbivora and man, but occasionally to other animals. Encapsulation is considered to be one of the factors that determines virulence of $B$. anthracis, because the capsule plays an important role in protecting the organism from phagocytosis and lytic antibodies (Preisz, 1909). On serum agar in the presence of excess $\mathrm{CO}_{2}$, virulent strains form smooth mucoid colonies consisting of fully virulent encapsulated organisms (Chu, 1952; Sterne, 1937a,b). On further incubation, however, rough outgrowth often occurs, subcultures from which give rough and non-mucoid colonies that consist of nonencapsulated bacilli. Non-encapsulated bacilli are uniformly avirulent, and reversion to the virulent encapsulated type has not been observed (Chu, 1952; Sterne, 1937a, b). Although the genetic mechanism of this variation is not clear, the so-called Sterne's strain, which is nonencapsulated but has immunizing activity, has been used as a live vaccine for anthrax.

There is now clear evidence that some of the virulence factors of bacteria are mediated by plasmids (Elwell \& Shipley, 1980). Mikesell et al. (1983) recently reported that $B$. anthracis harbours a large plasmid conferring the production of the toxins. Furthermore, Vodkin \& Leppla (1983) proved that this plasmid codes for the protective antigen, which is one of the anthrax toxins. In the course of our studies, we found that $B$. anthracis harbours two plasmids, with molecular masses of $110 \mathrm{MDal}$ and $60 \mathrm{MDal}$. This paper deals with the distribution of these plasmids in B. anthracis strains and the association of capsule formation with the $60 \mathrm{MDal}$ plasmid.

\section{METHODS}

Bacterial strains and growth conditions. The B. anthracis strains used are listed in Table 1. Bacterial cultures were grown at $37^{\circ} \mathrm{C}$ in Penassay broth (Difco) or on nutrient agar.

Plasmid isolation. Plasmid DNA was isolated by the method of Mikesell et al. (1983) except that bacterial lysates were deproteinized by extracting twice with phenol/chloroform as described by Kado \& Liu (1981). An equal volume of phenol/chloroform $(1: 1, \mathrm{v} / \mathrm{v})$ was added to the bacterial lysate, and the solution was emulsified by shaking briefly. The partially purified DNA was subjected to electrophoretic analysis for detection of plasmids. 


\section{Table 1. Strains of Bacillus anthracis}

\section{Strain}

Shikan

Morioka

Shizuoka

Pasteur no. 1

Pasteur no. 2-H

Pasteur no. 2-17JB

Davis

34F2

Smith

Mukteswer
Relevant characteristics*

$\mathrm{C}^{+}, \mathrm{SM}$, Virulent

$\mathrm{C}^{+}, \mathrm{SM}$, Virulent

$\mathrm{C}^{+}, \mathrm{SM}$, Virulent

$\mathrm{C}^{+}, \mathrm{SM}$, Attenuated

$\mathrm{C}^{+}, \mathrm{SM}$, Attenuated

$\mathrm{C}^{+}, \mathrm{SM}$, Attenuated

$\mathrm{C}^{+}, \mathrm{SM}$, Attenuated, $\mathrm{Spo}^{-}$

$\mathrm{C}^{-}, \mathrm{R}$, Attenuated

$\mathrm{C}^{-}, \mathrm{R}$, Attenuated

$\mathrm{C}^{-}, \mathrm{R}$, Attenuated
Reference or source $\dagger$

Ando et al. (1961 $a, b)$

Ando et al. (1961a)

Ando et al. (1961a)

Ando et al. (1961 a)

Ando et al. $(1961 a, b)$

CVL

Ando et al. (1961a)

Ando et al. (1961 a), CVL

Ando et al. (1961a)

Ando et al. (1961a)

${ }^{*} \mathrm{C}^{+}$, Encapsulated; $\mathrm{C}^{-}$, non-encapsulated; $\mathrm{SM}$ or $\mathrm{R}$, smooth or rough colony when cultivated on serum agar in the presence of $\mathrm{CO}_{2} ; \mathrm{Spo}^{-}$, asporogenous.

$\uparrow$ CVL, Central Veterinary Laboratory, Weybridge, UK.

For further purification, the plasmid DNA was recovered by means of caesium chloride/ethidium bromide density gradient centrifugation as described previously (Ohmae et al., 1981).

Restriction endonuclease digestion. The restriction endonucleases Bam $\mathrm{HI}$ and Pst I were obtained from Takara Shuzo Co., Kyoto, Japan. Plasmid DNA was digested as recommended by the supplier. The sizes of DNA fragments produced after digestion were estimated from their mobilities relative to HindIII-digested phage $\lambda$ DNA fragments.

Analytical gel electrophoresis. Gel electrophoresis was performed by the procedure of Meyers et al. (1976). The sample was electrophoresed through a horizontal or vertical $0.8 \%(\mathrm{w} / \mathrm{v})$ agarose gel at $100 \mathrm{~V}$ for $5 \mathrm{~h}$, using Tris/borate buffer ( $89 \mathrm{~mm}$-Tris, $2.5 \mathrm{~mm}$-EDTA, $8.0 \mathrm{~mm}$-boric acid). The gels were stained for $15 \mathrm{~min}$ with ethidium bromide $\left(0.5 \mu \mathrm{g} \mathrm{ml}^{-1}\right)$ and then washed for $15 \mathrm{~min}$ in distilled water.

Electron microscopical analysis. A modified formamide technique was used (Davis et al, 1971). Plasmid samples were spread from a hyperphase, containing $0.1 \mu \mathrm{g} \mathrm{DNA} \mathrm{ml}^{-1}$ in $60 \mathrm{mM}-\mathrm{Tris} / \mathrm{HCl}(\mathrm{pH} 8.5), 6 \mathrm{~mm}-\mathrm{EDTA}, 50 \%$ $(\mathrm{v} / \mathrm{v})$ formamide and $60 \mu \mathrm{g}$ cytochrome $c \mathrm{ml}^{-1}$, onto a hypophase of $18 \%(\mathrm{v} / \mathrm{v})$ formamide in $10 \mathrm{mM}-\mathrm{Tris} / \mathrm{HCl}$ $(\mathrm{pH} 8.5)$ and I mM-EDTA. The cytochrome $c$ layer with DNA was picked up on a Parlodion-coated grid, and was stained with uranyl acetate and shadowed with platinum/palladium $(80: 20)$. The mean contour length of open circular plasmid molecules was compared with that of plasmid RP4 (36.0 MDal).

Production of non-encapsulated variants. This was done by the method of Chu (1952). The bacterial cultures were grown on a nutrient agar containing $10 \%(\mathrm{v} / \mathrm{v})$ horse serum, and incubated in $20 \%(\mathrm{v} / \mathrm{v}) \mathrm{CO}_{2}$ at $37^{\circ} \mathrm{C}$ for several days. The rough irregular outgrowths that appeared around the smooth mucoid colonies were picked and purified. Capsule formation was determined microscopically after staining a heat-fixed smear with methylene blue solution for a few seconds (Doetsh, 1981).

\section{RESULTS}

Plasmid DNA contents of B. anthracis strains. Fig. 1 shows the plasmid contents of various strains of $B$. anthracis as revealed by electrophoretic analysis. Two plasmid species were detected in the three typical strains (Shikan, Morioka, Shizuoka) and the three Pasteur vaccine strains (no. 1, no. 2-H, no. 2-17JB). Strain Davis, which is avirulent and asporogenous but is encapsulated, harboured only the smaller plasmid, while the three non-encapsulated vaccine strains (34F2, Smith, Mukteswer) harboured only the larger plasmid. The molecular masses of these plasmids were estimated to be $110 \cdot 2 \pm 4.9 \mathrm{MDal}$ (SD; 14 molecules measured) and $60 \cdot 3 \pm$ 2.4 MDal (12 molecules measured) from their contour lengths in the electron microscope.

Plasmid DNA contents of non-encapsulated variants. Non-encapsulated variants were obtained from the encapsulated strains Shikan, Pasteur no. 1, Pasteur no. 2-17JB and Davis by the method of Chu (1952) and were examined, for the presence of plasmids, using electrophoretic analysis. As shown in Fig. 1, all the strains had lost the $60 \mathrm{MDal}$ plasmid.

Restriction endonuclease analysis of $B$. anthracis plasmids. The restriction endonuclease digestion patterns of the $110 \mathrm{MDal}$ and the $60 \mathrm{MDal}$ plasmids were different (Fig. 2). However, the cleavage patterns of the $110 \mathrm{MDal}$ plasmids from the non-encapsulated vaccine strain $34 \mathrm{~F} 2$ and from the non-encapsulated variant derived from strain 17JB, which had lost the $60 \mathrm{MDal}$ 


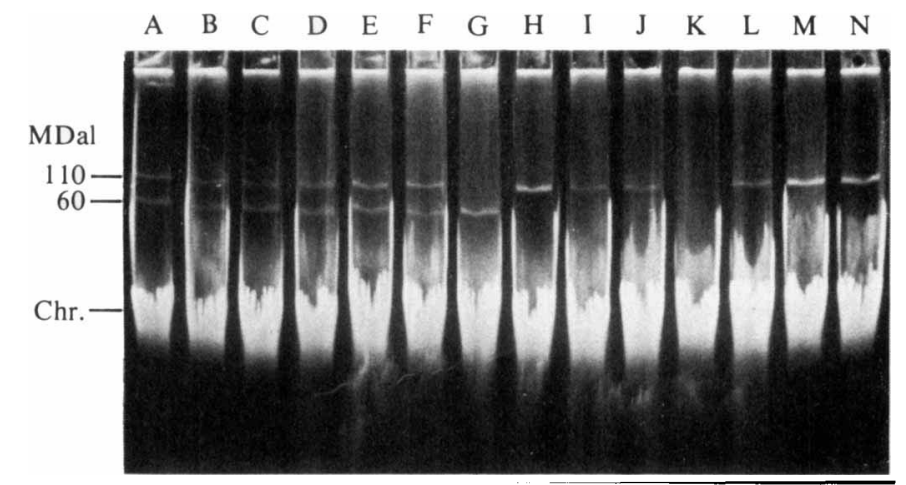

Fig. 1. Agarose gel electrophoresis of plasmid DNA isolated from various strains of $B$. anthracis. Partially purified plasmid DNA samples were subjected to electrophoresis through a vertical $0 \cdot 8 \%$ agarose slab gel at $100 \mathrm{~V}$ for $5 \mathrm{~h}$. The strains used were: Shikan (A), Morioka (B), Shizuoka (C), Pasteur no. 1 (D), Pasteur no. 2-H (E), Pasteur no. 2-17JB (F), Davis (G), 34F2 (H), Smith (I), Mukteswer (J), and non-encapsulated variants of Davis (K), Shikan (L), Pasteur no. 1 (M) and Pasteur no. 2-17JB (N). The dense bands are chromosomal DNA (Chr.).

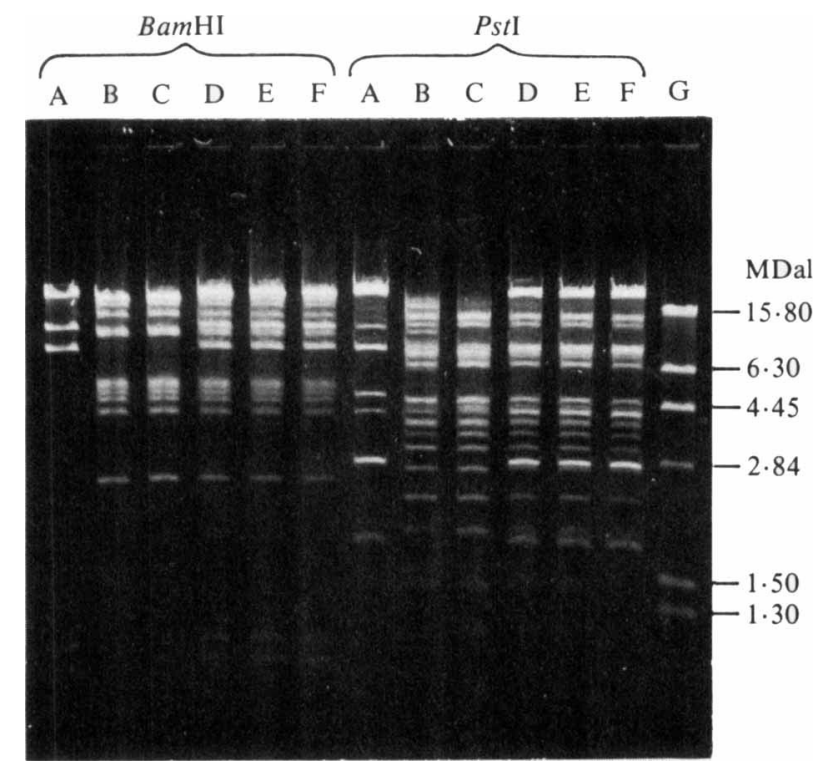

Fig. 2. Comparison of the restriction cleavage patterns of plasmid DNA isolated from various strains of $B$. anthracis. Purified plasmid DNA was subjected to restriction endonuclease digestion and electrophoresis through a horizontal $0.8 \%$ agarose slab gel at $100 \mathrm{~V}$ for $5 \mathrm{~h}$. Strains: (A) Davis (60 MDal plasmid), (B) 34F2 (110 MDal plasmid), (C) non-encapsulated variant of strain 17JB (110 MDal plasmid), (D) mixture of Davis and 34F2 (60 MDal and $110 \mathrm{MDal}$ plasmids), (E) 17JB (60 MDal and $110 \mathrm{MDal}$ plasmids), (F) Shikan $(60 \mathrm{MDal}$ and $110 \mathrm{MDal}$ plasmids). Phage $\lambda$ DNA digested with HindIII was run in parallel as a size marker (G). Partial digestion products are seen in lanes Pst I-A and Pst I-B.

plasmid, were indistinguishable. The $110 \mathrm{MDal}$ plasmid yielded at least nine BamHI cleavage fragments $(>15 \cdot 8,>15 \cdot 8,15 \cdot 8,10 \cdot 6,6 \cdot 0,5 \cdot 2,4 \cdot 9,4 \cdot 3,2 \cdot 5 \mathrm{MDal})$ and 15 Pst $\mathrm{I}$ cleavage fragments $(15 \cdot 5,14 \cdot 7,11 \cdot 3,9 \cdot 7,9 \cdot 3,8 \cdot 0,5 \cdot 0,4 \cdot 7,4 \cdot 6,4 \cdot 5,4 \cdot 0,3 \cdot 3,2 \cdot 8,2 \cdot 3,2 \cdot 0 \mathrm{MDal})$. The restriction cleavage pattern of a mixed sample of $34 \mathrm{~F} 2(110 \mathrm{MDal})$ and Davis $(60 \mathrm{MDal})$ plasmids was the same as those of $17 \mathrm{JB}$ (110 MDal and $60 \mathrm{MDal})$ and Shikan (110 MDal and $60 \mathrm{MDal}$ ), suggesting that the $60 \mathrm{MDal}$ plasmids present in various strains are also identical. The $60 \mathrm{MDal}$ plasmid yielded at least five Bam HI cleavage fragments $(>15 \cdot 8,13 \cdot 3,8 \cdot 0,1 \cdot 2,0 \cdot 4 \mathrm{MDal})$ and five $P$ st I cleavage fragments (>15.8, 8.7, 4.2, 2.8, 1.9 MDal). 


\section{DISCUSSION}

The present study has shown that most of the strains of $B$. anthracis that we examined contained two plasmid species with molecular masses of $110 \mathrm{MDal}$ and $60 \mathrm{MDal}$. To isolate the plasmid DNA from $B$. anthracis, we deproteinized bacterial lysates twice with phenol/chloroform; plasmids could only rarely be isolated without this deproteinization step. The restriction endonuclease digestion patterns of the $110 \mathrm{MDal}$ and the $60 \mathrm{MDal}$ plasmids were quite different, indicating that the $110 \mathrm{MDal}$ plasmid is not a dimer of the $60 \mathrm{MDal}$ plasmid. The various $110 \mathrm{MDal}$ plasmids examined were indistinguishable from each other, regardless of their origin, which suggests that they share a common ancestry. Similar results were obtained with the various $60 \mathrm{MDal}$ plasmids, suggesting that these plasmids also share a common ancestry.

Restriction analysis also showed that the $110 \mathrm{MDal}$ plasmids obtained in this study are very similar to plasmid pBAl which encodes the production of the protective antigen of B. anthracis (Vodkin \& Leppla, 1983). Mikesell et al. (1983) reported that the $110 \mathrm{MDal}$ plasmids, including pBA1, could be cured by serial passages at high temperature $\left(42.5^{\circ} \mathrm{C}\right)$; hence, Pasteur vaccine strains which had been attenuated by repeated subculture at an elevated temperature contained no detectable plasmids. We found that the $110 \mathrm{MDal}$ plasmids of two strains (Shikan, 34F2) could be eliminated by serial passages at $42.5^{\circ} \mathrm{C}$ (data not shown), suggesting that the $110 \mathrm{MDal}$ plasmids of these strains may be temperature-sensitive, as reported by Mikesell et al. (1983). However, the three Pasteur vaccine strains (no. 1, no. 2-H, no. 2-17JB) examined in this study still harboured two plasmid species of $110 \mathrm{MDal}$ and $60 \mathrm{MDal}$. Although we have no evidence to explain this discrepancy, it is possible that the $110 \mathrm{MDal}$ plasmid might have been integrated into the host chromosome and that excision then occurred after many subcultures in the laboratory.

With regard to the $60 \mathrm{MDal}$ plasmid in B. anthracis, Mikesell et al. (1983) have found a plasmid of this size in strain Vollum IB by electron microscopic analysis. However, the presence of $60 \mathrm{MDal}$ plasmids in other strains has not previously been noted. In the present study, we consistently demonstrated the presence of the $60 \mathrm{MDal}$ plasmid in encapsulated $B$. anthracis strains, including virulent and attenuated strains. In contrast, this plasmid was not present in the non-encapsulated strains 34F2, Smith and Mukteswer, which have been used as live vaccine strains in various countries. Moreover, it was found that the non-encapsulated variant strains obtained in this study from the encapsulated strains Shikan, Pasteur no. 1, Pasteur no. 2-17JB and Davis had lost the $60 \mathrm{MDal}$ plasmid. These results strongly suggest that encapsulation of $B$. anthracis is mediated by the $60 \mathrm{MDal}$ plasmid. The lack of a direct selection procedure, however, makes it difficult to introduce the $60 \mathrm{MDal}$ plasmid into non-encapsulated variant strains of $B$. anthracis. Further study is now in progress to confirm the function of the $60 \mathrm{MDal}$ plasmid in B. anthracis.

We are grateful to Dr K. Ando, Research Centre for Veterinary Science of the Kitasato Institute, for his help during this study.

\section{REFERENCES}

Ando, K., Akaike, Y. \& Azuma, R. (1961 $a$ ). Identification of Bacillus anthracis by means of $\gamma$ bacteriophage. National Institute of Animal Health Quarterly 41, 37-41.

ANDO, K., AKaIKe, Y. \& Moriya, Y. (1961b). Attenuation of Bacillus anthracis by penicillin and immunogenicity of the attenuated organisms. Bulletin of the Azabu Veterinary College $\mathbf{8}, 34-45$.

CHU, H. P. (1952). Variation of Bacillus anthracis with special reference to a non-capsulated avirulent variant. Journal of Hygiene 50, 433-444.

Davis, R. W., Simon, M. \& Davidson, N. (1971). Electron microscope heteroduplex methods for mapping regions of base sequence homology in nucleic acids. Methods in Enzymology 21, 413-428.
DOETSH, R. N. (1981). Determinative methods of light microscopy. In Manual of Methods for General Bacteriology, pp. 21-33. Edited by P. Gerhardt, R. G. E. Murray, R. N. Costilow, E. W. Nester, W. A. Wood, N. R. Krieg \& G. B. Phillips. Washington, DC: American Society for Microbiology.

Elwell, L. P. \& Shipley, P. L. (1980). Plasmidmediated factors associated with virulence of bacteria to animals. Annual Review of Microbiology 34, 465-496.

KADO, C. I. \& LIU, S.-T. (1981). Rapid procedure for detection and isolation of large and small plasmids. Journal of Bacteriology 145, 1365-1373.

Meyers, J. A., Sanchez, D., Elwell, L. P. \& FALKow, S. (1976). Simple agarose gel electrophore- 
tic method for the identification and characterization of plasmid deoxyribonucleic acid. Journal of Bacteriology 127, 1529-1537.

Mikesell, P., Invis, B. E., Ristroph, J. D. \& Dreier, T. M. (1983). Evidence for plasmid-mediated toxin production in Bacillus anthracis. Infection and Immunity 39, 371-376.

Ohmae, K., Yonezawa, S. \& Terakado, N. (1981). R plasmid with carbadox resistance from Echerichia coli of porcine origin. Antimicrobial Agents and Chemotherapy 19, 86-90.

PreIsz, H. (1909). Experimentelle Studien über Virulenz, Empfänglichkeit und Immunität beim Milzbrand. Zentralblatt für Bacteriologie, Parasitenkunde und Infektionskrankheiten, Abteilung Originale 49, 341-452.

STERNE, M. (1937a). Variation in Bacillus anthracis. Onderstepoort Journal of Veterinary Science and Animal Industry 8, 271-349.

Sterne, M. (1937b). The effects of different carbon dioxide concentrations on the growth of virulent anthrax strains. Pathogenicity and immunity tests in guinea-pigs and sheep with anthrax variants derived from virulent strains. Onderstepoort Journal of Veterinary Science and Animal Industry 9, 49-67.

Vodkin, M. H. \& Leppla, S. H. (1983). Cloning of the protective antigen gene of Bacillus anthracis. Cell 34, 693-697. 